\title{
Religious Extremism versus Extremes of Desacralisation: Rethinking the Status of Religious Education
}

\author{
Abdurezak Abdulahi Hashi \\ $\mathrm{PhD}$ Associate Professor, Department of Biotechnology, \\ Kulliyyah of Science, International Islamic University Malaysia \\ hashi@iium.edu.my
}

\begin{abstract}
Religion has been part and parcel of human history and heritage. It has served as a useful companion to man in the journey of intellectual growth, which has in most of the cases, helped humanity to answer, in various forms, the basic questions of life. Though religion has been a useful companion to man, yet religious thought has never been without challenges. There have been instances in which religion is challenged by strong tendencies of secularism and the process desacralisation of politics, ethics and values, in which traditional territories of religion in life are rolled back. On the contrary, religious extremism has been another challenge of religious life, in which violent act were committed in the name of religion. Modern proponents of extreme secularism have equated religion to infantile and childish expressions of man which functions as obstacle to the scientific mind of man, therefore they say in the age of science; religion should disappear once for all. However, contemporary religious extremists exhibit the behavior of imposing their religious thoughts violently; they do so by demonize other religious faiths as well as ideologies and philosophies other than their own, and thus feel justified to use violent behavior against those who hold different beliefs and ideas. The question is, other than denying "the value of religion in life" or "demonizing other faiths", can there be other intellectual positions towards religion? This paper uses analytical method to address common trends of intellectual extremism for or against religious education; be it in the form of secular or religious thought. It re-examines the status
\end{abstract}


of religious education in modern times, and the challenges posed by intellectual extremisms against the function and the role of religious education in life. KEY WORDS: intellectual extremism, religion, challenges, exposition.

\section{Introduction}

Extremism reflects the quality of being extreme and the tendency of advocating opinions that are beyond the established norms. In the world of ideas, politics and beliefs, this term is often used to identify those who promote an ideology and practices that are considered to be far outside the mainstream thoughts and attitudes of established schools of thought or institutions. In this paper though, secular extremism is understood as those intellectuals and activists whose writings do not only reflect separation of religion from public life, but anticipate the demise of religious faiths, and thus disappear once for all. Religious education is faced by a number of difficulties including the challenges of desacraliztion and religious extremism. The former aims to eliminate religious traditions from public arena and replace it with humanism or human generated ideas. The practices of the later exceed the boundaries of religion, whereby the noble aims of religious traditions are not appreciated.

\section{Religious education and the challenges of religious extremism}

Religious extremism is understood as the religious perspectives that demonize those with different religious faiths, or with the opposing viewpoints, and characterize people as either "fully for" or "fully against" the own group's religious views, and identifying certain people outside the religion or the group as having less innate value on basic human level (Alex Zorach 2010). Religious extremism should not however be confused with religious conservativism and fundamentalism. The former is marked by commitment to the traditional values and ideas with some sort of opposition to innovations, while the later reflects the attitude of seeking the roots or the foundations of their religious beliefs. Regardless of the causes of religious extremism (Colonel Ahmad Al-Thagafi 2008; Iannaccone 1999), be it lack of purpose, spirit and essence of knowledge, or occupation with side issues with observable negligence of religious essence, excessive extension of prohibitions, misunderstanding of certain textual narrations, or assuming the infallibility of scholars, religious extremist are often associated with deviation from the teachings of the mainstream of given religious tradition or school of thought that they belong to. With fanatic dogmas and narrow-mind, religious extremists see themselves as holier-than-thou and condemn the religious practices of the society with 
dogmatic certainty, promoting themselves as having a monopoly of the religious truth. Not only that religious extremism tend to demonize those with other religious view other than their own, but religious extremists are often associated with intolerance and aggressive behavior towards others, in which they seek to impose their religious or ideological views on others. For religious extremism is often marked by uncritical zeal, with obsessive admiration of one's own religious opinions, religious extremists often deviate from the essence and ultimate aims of the religious teachings. Regardless of its forms and causes, religious extremism constitutes a real challenge to the functions and roles of religious education in life. This is so because, while learned scholars of given religious traditions often argue that religion aids or complements human mind, with religious extremism religious education loses its true sense and purpose.

\section{Religious education and the challenges of desacralisation}

Back in the early modern history particularly, during the age of European Enlightenment, and in the subsequent periods, tendencies of rolling back religious territories in life have emerged. In this tendencies, the validity of revelation, the traditional source of religious teachings were questioned, while ideas and thoughts that are derived from human reason and scientific knowledge were very much anticipated. With the mind that science and reason are enough to explain life and thus solve the problems of humanity, calls to diminish and possibly illuminate religious influences in public life, were made, a process which is known as secularization. It begins as an intellectual position that is concerned "only with questions, the issues of which can be tested by the experience of this life" (Holyoake 1896, 61). With the mind that reason, experiment and observation of natural cause and effect relationships in the natural world are the ways to understand life, secularism is driven by the process of desacralizing public life. Desacralization involves two interrelated steps; firm refusal of acknowledging the traditional authority and functions of divine teachings in philosophy, ethics and politics. It also tends to eliminate divine teachings from public domains (Max Webber d.1920) (Weber 2009; 1993). Though the initial phase of desacralization was very much driven by the tendency of managing state affairs and public life based on the dictates of human reason, without making reference to the divine sources, in the $18^{\text {th }}$ and $19^{\text {th }}$ centuries on words, desacralization tendencies were very much strengthened. Philosophers like, Karl Marx (d. 1883), Nietzsche (d.1900), Charles Darwin (d.1882), Sigmund Freud (d. 1939), and others, adopted philosophies and interpretations of nature in which religious traditions played little role, and in some aspects were seen as merely an irrational human product, which lacked the necessary rational consistency 
and intellectualism. Towards the end of the $19^{\text {th }}$ century, the West experienced the rise of atheistic philosophies, which announced their independence from belief in God. Modern philosophers like Karl Marx, Friedrich Nietzsche and Sigmund Freud, categorically presented scientific interpretations of life, in which not only was the idea of a creator God was absent, but some of these philosophers were deliberately calling for the death of God, who must forth disappear forever from life. These ideas have gradually spread throughout the materialistic and positivistic traditions of modern philosophy. For instance, philosophers like (Schopenhauer d.1860), argued that, in the age of science, man does not need to believe in the existence of God for the reason that God, if he existed, would be evil. (Further readings about Arthur Schopenhauer's conception of religion and human nature is found in Schopenhauer 2015).

On his part, German linguist, Nietzsche loudly announced that "God is dead, and He remains dead. And we have killed him" (Nietzsche 1974, 119-120) he equates religion to an infantile idea and crime against humanity, hence in the age of science, God should disappear from life once and for all (Nietzsche 1974, 119-120). Karl Marx equated religion with "social opium" (Marxists Internet Archive 1843), and a tool of "social alienation" (Marxists Internet Archive 1843), while in his book The Future of an Illusion, Sigmund Freud $(1989,39)$, equated religion to illusory myths and superstitions, which have no future in the face of science.

Regardless of the intensity and depth of the works of these scholars, religious communities have always resisted, and most of the cases brushed aside the conclusions of these approaches about religious traditions. This is because, in the eye of religious communities, these hostile approaches are marked by an observable intellectual extremism towards the validity and functions of religious thought with severe methodological shortcomings, and thus their conclusions about religious traditions are not worthy.

\section{Rethinking the Status of Religious Education}

For religious communities, as well as observers of religion and for every individual who wants to be informed about the world around, religion is an intensely inquisitive phenomenon that calls out for positive understanding of life. Hence, given the presence of religious traditions in today's societies and their cultures, the author is of the view that denial of religious traditions' right to exist or anticipations of the demise of religious tradition, as reflected in the extremes of the tendencies of desacralization, is counterproductive and would certainly prevent us from understanding the proper meaning and the role of religious teachings in life. Religious extremism too surely does 
not help us to appreciate the true meaning and the value of religious teachings. Hence, other than the extremes of secularism and religious fanatics, can there be other ways of appreciating the true role and functions of religious teachings in life?

In the search for proper answer to this question, we must bear in mind few realities about religious traditions; first, regardless of our intellectual positions about the function and the value of religious traditions in life, we must admit the fact that religion is present in all aspects of human life; in politics, in culture, in knowledge, in thoughts, in values, in music, in arts, in global issues and conflicts.

Second, not only that religion is present in our life, but despite the modern secular contentions of isolating religion from the domains of the public life, religious traditions hold an observable degree of influence on worldviews and ways of life, particularly in the categories of thought by means of providing answers to the basic inquires about the origin, the nature and the ultimate goals of life to the most of the global societies of the present age, and will certainly provide the same in the future.

Third, unlike conventional ideologies, religious teachings provoke strong convictions, heartfelt commitment, eloquent expression, forthright action, and thus play a significant role to shape the basic categories of our conceptions of life and features of cultural identities (Hashi 2014,123). Throughout history, religion"has expressed the deepest questions human beings can ask, and it has taken a central place in the lives of virtually all civilizations and cultures. As we think all the way back to the dawn of human consciousness, we find religion everywhere we turn"(The American Academy of Religion 2004).

Fourth, proponents of desacrilization, like Bertrand Russell have argued that, with the rise of science and the expansion of technology, the age of religion is coming to an end, whereby science will replace religion. However, the fact that "more than three-quarters of the world's people identify with one or more religions" (Van Voorst $2015,9)$ presumably implies that religious beliefs are not fading away, rather religion is persistent and shows no signs of disappearing; hence suggestions of the demise of religion seem to be premature rumours.

Fifth, religious teachings are not "scientific" facts which could be coldly examined in the manner of biological or chemical samples; and thus, to a limited extent, the rites, ritual and organized institutions of religion, as well as their development and history can be studied in this way (Al-Faruqi 1967, 4). Unlike scientific facts in which the researcher could remain an outsider and keep a cold' distance from the phenomenon under study, to gain an insight into the 'life-fact' of a religion, we must imagine and allow our understanding to be touched and informed by them. The longer we can 
sustain this effort of imagination, the deeper will be our experience of the religious teachings, and the deeper (and more reliable) our insights are into it. This is to say that religion is a combination of two things; "life" and "facts"; on the one hand, religious teachings cover life experiences, ideas, thoughts and inspirations, while it also covers observable facts, on the other hand. Hence,"unless and until we are willing to be with and inside the 'life-facts' we are studying, they will not yield their meaning to us" (AlFaruqi 1967, 4).

\section{Conclusion}

Extremisms of desacralization and religious fanatics constitute significant challenges of appreciating the proper functions and roles of religious education in life. Both of these extremes are presenting unrealistic views about the meaning and the value of religious traditions in life. Hence, unless and until the challenges of religious extremism and that of desacralization, towards religious thought, are duly addressed and solved, religious education would not be duly appreciated.

\section{References}

Al-Faruqi, Ismail Raji. 1967. Christian Ethics: A Historical and Systemic Analysis of its Dominant Ideas. Montreal: McGill University Press.

Colonel Ahmad Al-Thagafi. 2008. Causes and Possible Solutions to the Middle East Terrorism. USAWC CLASS OF 2008, Carlisle Barracks, PA: US Army War College. file://C:/ Users/iium.Pc/Downloads/ADA481469.pdf, retrieved 08/10/2017.

Freud, Sigmund. 1989. The Future of an Illusion. Translated and edited by James Strachey. New York: Norton.

Hashi, Abdurezak A. 2014. The Study of Religious Traditions. Kuala Lumpur: IIUM Press.

Holyoake, George Jacob. 1896. English Secularism: A Confession of Belief. Chicago: The Open Court Publishing Company.

Iannaccone,Laurence R.1999."Religious Extremism: Origins and Consequences.” Contemporary Jewry. December 1999. https://www.researchgate.net/publication/225744337 _ Religious_extremism_Origins_and_consequences, retrieved 08/10/2017.

Marxists Internet Archive. 1843. "Works of Karl Marx, A Contribution to the Critique of Hegel's Philosophy of Right." Proofed and corrected by Andy Blunden, February 2005, and corrected by Matthew Carmody in 2009. https://www.marxists.org/archive/marx/ works/1843/critique-hpr/intro.htm, retrieved 03 September, 2015. 
Nietzsche, Friedrich Wilhelm. 1974. The Gay Science: with a Prelude in Rhymes and an Appendix of Songs. New York: Vintage Books.

Schopenhauer, Arthur. 2015. On Human Nature. Translated by T. Bailey Saunders, M.a., (web edition published by eBooks@Adelaide. South Australia 5005: The University of Adelaide Library. https://ebooks.adelaide.edu.au/s/schopenhauer/arthur/human/ titlepage.html, retrieved 03 September 2015.

The American Academy of Religion. Why study Religion? http://studyreligion.org/site/about. html. Retrieved: 30/09/2017.

Van Voorst, Robert E. 2015. Relg: World 2. USA: Cengage Learning.

Weber, Max. 1993. The Sociology of Religion. Boston: Beacon Press.

Weber, Max. 2009. From Max Weber: Essays in sociology. New York: Routledge. 